\title{
ANALISIS FINANSIAL DAN STRATEGI PENGEMBANGAN USAHA KECIL MENENGAH (UKM) KACANG VERNIS
}

\author{
Haryati Lakamisi*, Rukiaty Usman* \\ Staf Pengajar FAPERTA UMMU-Ternate, $e$-mail: -
}

\begin{abstract}
ABSTRAK
Penelitian ini bertujuan untuk menentukan strategi pengembangan usaha kacang vernis melalui tahapan analisis kelayakan finansial dan analisis SWOT. Analisis data diolah dalam bentuk ditabulasi, kemudian dianalisis secara matematis dengan merujuk pada aspek-aspek perhitungan analisis kelayakan finansial, yaitu Break Event Point (BEP), Net Present Value (NPV), Payback Period (PBP), Internal Rate of Return (IRR), B/C Rasio dan Analisis SWOT. Dari hasil analisis kelayakan finansial UKM kacang vernis "M. Nasir" menunjukkan bahwa usaha ini layak dan menguntuntungkan karena memberikan nilai NPV yang positif, yaitu sebesar Rp 167.396.449, nilai IRR sebesar 178\%, atau lebih besar dari bunga bank yang berlaku yaitu 9\%, nilai Net B/C Ratio yaitu sebesar 6,98, nilai BEP sebesar 2.612,544 bungkus dan nilai PBP sebesar 1,1 tahun. Dari hasil analisis biaya, pendapatan, dan keuntungan diketahui bahwa usaha kacang vernis mengeluarkan biaya sebesar $R p 57.475 .967$ per tahun yang terdiri dari biaya tetap sebesar $R p$ 2.439.167 dan biaya variabel sebesar $R p$ 55.036.800. Pendapatan yang diperoleh produsen dari usaha kacang vernis adalah sebesar $R p 107.712 .000$ per tahun. Laba atau keuntungan yang diperoleh produsen adalah sebesar $R p$ 50.236.033 per tahun. Dari hasil analisis SWOT diperoleh skor faktor internal sebesar 3,2 dan faktor eksternal sebesar 3,16 sehingga strategi yang tepat untuk diterapkan adalah strategi stabilitas.
\end{abstract}

Kata Kunci: Kacang vernis, pengembangan usaha, strategi finansial.

I. PENDAHULUAN

1.1. Latar Belakang

Keberadaan Usaha Kecil Menengah (UKM)

di Indonesia tidak dapat dipungkiri telah memberikan kontribusi bagi perekonomian Indonesia dalam menyumbang Produk Domestik Bruto (PDB), penyerapan tenaga kerja, pengurangan jumlah kemiskinan, pemerataan dalam distribusi pendapatan, dan pembangunan ekonomi di pedesaan (Simatupang et al.,1994; Kuncoro, 1996).

Mengingat sumbangsih UKM yang besar terhadap perekonomian Indonesia, maka UKM perlu mendapat perhatian dan kebijakan pemerintah untuk dikembangkan dan meningkatkan kinerjanya. Apalagi karena lokasinya banyak di pedesaan, pertumbuhan UKM akan menimbulkan dampak positif karena tidak hanya memberikan penghasilan bagi sebagian besar angkatan kerja Indonesia, tetapi juga merupakan ujung tombak dalam upaya pengentasan kemiskinan. Di pedesaan, peran penting UKM memberikan tambahan pendapatan (Sandee et al., 1994) merupakan seedbed bagi pengembangan industri dan sebagai pelengkap produksi pertanian bagi penduduk miskin (Weijland, 1999). Dengan kata lain, UKM berfungsi pula sebagai strategi mempertahankan hidup (survival strategy) di tengah krisis moneter.

Namun, disadari pula bahwa pengembangan usaha kecil menghadapi beberapa kendala seperti tingkat kemampuan, keterampilan, keahlian, manajemen sumber daya manusia, kewirausahaan, pemasaran dan keuangan. Lemahnya kemampuan manajerial dan sumber daya manusia mengakibatkan pengusaha kecil tidak mampu menjalankan 
usahanya dengan baik. Secara lebih spesifik, berikut adalah masalah dasar yang dihadapi pengusaha kecil, yaitu: 1) kelemahan dalam memperoleh peluang pasar dan memperbesar pangsa pasar; 2) kelemahan dalam struktur permodalan dan keterbatasan untuk $\square$ memperoleh jalur terhadap sumber-sumber permodalan; 3) kelemahan di bidang organisasi dan manajemen sumber daya manusia; 4) keterbatasan jaringan usaha kerja sama antar pengusaha kecil (sistem informasi pemasaran); 5) iklim usaha yang kurang kondusif karena persaingan yang saling mematikan; dan 6) pembinaan yang telah dilakukan masih kurang terpadu dan kurangnya kepercayaan serta kepedulian masyarakat terhadap usaha kecil (Kuncoro, 2007).

Analisis kelayakan finansial relatif sudah banyak mendapatkan perhatian dari para akademisi untuk analisis di berbagai bidang industri (Kusuma, 2010; National Association of Certified Valuation Analysts, 2005; Sutojo, 2000). Selain itu, analisis kelayakan finansial juga dilaksanakan oleh para pelaku di bidang industri manufaktur menggunakan berbagai metode (Firmansyah, 2006; Wolf, 2005; Mc. Keough, 2005) dan termasuk juga pada industri berbasis agro atau pertanian (Erlina, 2006; Rantala, 2010). Selain menggunakan analisis kelayakan finansial juga menggunakan analisis SWOT dengan menentukan faktor lingkungan eksternal dan faktor lingkungan internal UKM kemudian melakukan penilaian terhadap masing-masing faktor lingkungan eksternal dan faktor lingkungan internal bagi UKM.

Pengembangan UKM kacang vernis “ $M$. Nasir" mengalami keterbatasan modal peralatan yang akan digunakan untuk peningkatan kapasitas produksi. Keterbatasan tekonologi peralatan yang dikuasai UKM menyebabkan kapasitas produksinya terbatas, sehingga keuntungan yang diterima produsen belum maksimal. Adanya keterbatasan teknologi peralatan yang digunakan, dapat menyebabkan ketidakmampuan UKM kacang vernis memberikan nilai tambah yang nyata bagi keberlangsungan usahanya. UKM kacang vernis "M. Nasir" akan melakukan peningkatan kapasitas produksi melalui penambahan modal untuk teknologi peralatan, sarana dan prasarana produksi. Oleh karena itu UKM kacang vernis "M. Nasir" memerlukan Analisis kelayakan finansial untuk mengetahui, apakah dengan adanyapenambahan modal untuk teknologi peralatan, sarana dan prasarana produksi, usaha ini masih layak untuk dikebambangkan dan untuk mengetahui apakah UKM kacang vernis “M. Nasir" mampu mengembalikan modal pinjaman tersebut.

\subsection{Tujuan Penelitian}

Penelitian ini bertujuan untuk:

1. Menentukan strategi finansial pengembangan usaha kacang vernis melalui analisis kelayakan finansial dalam meningkatkan kapasitas produksi dan pinjaman modal.

2. Menganalisis kondisi lingkungan internal (kekuatan dan kelemahan) dan lingkungan eksternal (peluang dan ancaman) pengembangan usaha kecil menengah kacang vernis.

3. Merumuskan strategi yang tepat untuk pengembangan usaha kecil menengah kacang vernis.

\section{METODE PENELITIAN}

\subsection{Lokasi dan Waktu Penelitian}

Penelitian ini dilaksanakan di UKM kacang vernis "M. Nasir" yang berlokasi di kelurahan Jati Metro Kota Ternate selama tiga bulan dari bulan Juni sampai bulan Agustus 2015.

\subsection{Jenis,Sumber, dan Teknik Pengumpulan Data}

Data pada penelitian ini diperoleh melalui data primer (wawancara, observasi, FGD, dan kuesioner) dengan pemilik usaha dan data sekunder diperoleh dari instansi terkait yang berhubungan dengan penelitian, buku dan internet. Responden yang digunakan ada dua kelompok yaitu pemilik usaha kacang vernis dan konsumen kacang vernis yang ditentukan sebanyak 50 orang. Perhitungan bobot dan rating dalam analisis SWOT menggunakan dua cara yaitu menggunakan FGD (Focus Group Discussion) dan kuisioner. FGD untuk memetakkan masalah sebagai kriteria dalam analisis SWOT dengan menggunakan 4 
responden yang terdiri dari 1 orang pemilik usaha, 1 orang bagian produksi, dan 2 orang bagian pemasaran.

\subsection{Teknik Analisis Data}

Untuk menjawab tujuan penelitian pertama maka digunakan perhitungan analisis kelayakan finansial, yaitu Break Event Point (BEP), Net Present Value (NPV), Payback Period, Internal Rate of Return (IRR), Rasio B/C

1. Menganalisis total biaya produksi dihitung dengan rumus menurut Soekartawi (2006) sebagai berikut:

$$
\mathrm{TC}=\mathrm{VC}+\mathrm{FC}
$$

$$
\begin{aligned}
& \text { Dimana: } \text { TC }=\text { Total Cost } \\
& \text { VC }=\text { Variabel Cost } \\
& \text { FC }=\text { Fixed Cost }
\end{aligned}
$$

2. Menganalisis HPP dihitung dengan rumus menurut Idham (2011) sebagai berikut:

$$
\text { Harga Produksi }=\frac{T C}{\text { Kapasitas Aktual }}
$$

3. Menganalisis penerimaan dihitung dengan rumus menurut Soekartawi (2006) sebagai berikut:

Penerimaan $=$ HargaJual $x \sum$ Produksi

4. Menganalisis BEP dihitung dengan rumus menurut Shinta (2011) sebagai berikut:

$$
\begin{aligned}
& \text { BEP unit }=\frac{F C}{P-V C} \quad \text { atau } \\
& \text { BEP rupiah }=\frac{F C}{1-V C / P}
\end{aligned}
$$

Dimana: $\quad F C=$ Biaya Tetap

$P \quad=$ Harga jual per unit

$\mathrm{VC}=$ Biaya Variabel per unit

5. Menganalisis NPV dihitung dengan rumus menurut Shinta (2011) sebagai berikut:

$$
\mathrm{NPV}=\sum_{t=1}^{n} \frac{(B t-C t)}{(1+i)^{t}}
$$

Dimana: $B t=$ Benefit pada tahun ke-t

$$
\begin{aligned}
\mathbf{C} t & =\text { Biaya pada tahun ke-t } \\
\mathbf{t} & =\text { lamanya waktu investasi } \\
\mathbf{i} & =\text { tingkat bunga }
\end{aligned}
$$

$$
\begin{aligned}
& \text { Jika: } \text { NPV }>0=\text { usaha layak } \\
& \text { NPV }=0=\text { usaha impas } \\
& \text { NPV }<0=\text { usaha tidak layak }
\end{aligned}
$$

6. Menganalisis IRR dihitung dengan rumus menurut Shinta (2011) sebagai berikut:

$$
\operatorname{IRR}=i_{1}+\frac{N P V_{1}}{N P V_{1}-N P V_{2}}\left(i_{2}-i_{1}\right)
$$

Dimana:

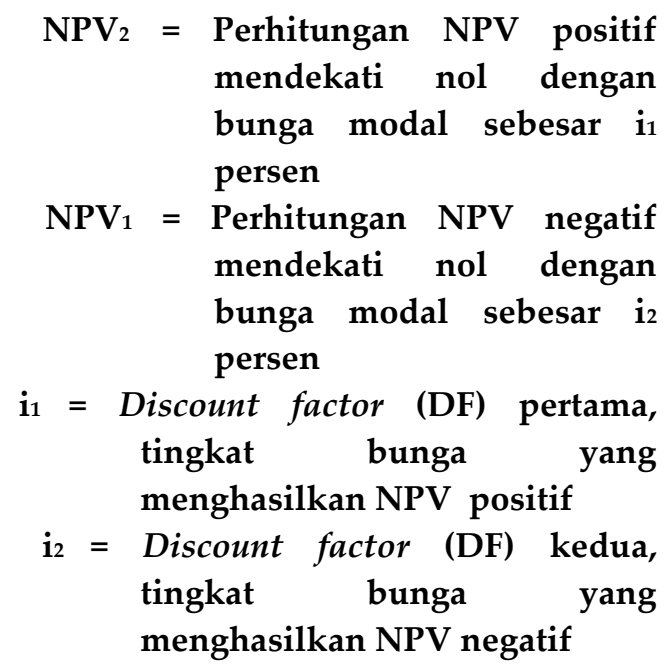

Jika:

IRR $>$ Sosial Discount Rate $=$ usaha layak IRR $<$ Sosial Discount Rate $=$ usaha tidak layak

7. Menganalisis PBP dihitung dengan rumus menurut Pudjosumarto (1991) sebagai berikut:

$$
\mathrm{PBP}=\frac{I}{A_{b}}
$$

\section{Dimana:}

$$
\begin{aligned}
\mathrm{I}= & \text { besarnya biaya investasi yang } \\
& \text { diperlukan } \\
\mathrm{A}_{\mathrm{b}}= & \text { benefit bersih yang dapat } \\
& \text { diperoleh setiap tahunnya }
\end{aligned}
$$

8. Menganalisis $\mathrm{B} / \mathrm{C}$ Rasio dihitung dengan rumus menurut Shinta (2011) sebagai berikut:

$$
\mathrm{B} / \mathrm{C} \text { Rasio }=\frac{\sum_{i=1}^{n} \frac{B t}{(1+i) t}}{\sum_{i=1}^{n} \frac{C t}{(1+i) t}}
$$


Dimana: $\mathrm{Bt}=$ Bebefit pada tahun ke-t

$\mathrm{Ct}=$ Biaya pada tahun ke- $\mathrm{t}$

$\mathrm{i}=$ tingkat bunga yang berlaku

$t=$ jangka waktu proyek

$\mathrm{n}=$ umur proyek

Jika: $\mathrm{B} / \mathrm{C}>1$ = Layak

$\mathrm{B} / \mathrm{C}<1$ = Tidak Layak

\section{Analisis SWOT}

Untuk menjawab tujuan penelitian kedua maka digunakan formulasi matriks IFE (InternalFaktor Evaluation) dan EFE (External Faktor Evaluation). Untuk menjawab tujuan penelitian ketiga dilakukan analisis dengan matriks Internal-Eksternal dan SWOT.

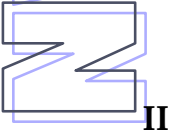

\section{HASIL DAN PEMBAHASAN}

\subsection{Analisis Finansial}

Analisis kelayakan usaha menggambarkan layak atau tidaknya suatu usaha, baik dari segi ekonomis, teknis, maupun finansial. Hasil dari analisis kelayakan usaha itu akan menentukan langkah lebih lanjut dari para pengusaha.

Titik berat analisis finansial adalah aspek keuangan, terutama lalu lintas uang (cash flow) yang terjadi selama kegiatan usaha. Indikator yang dipilih perlu disesuaikan dengan kebutuhan jenis dan skala usaha. Analisis usaha yang digunakan berupa Break Event Point (BEP), Net Present Value (NPV), Payback Period, Internal Rate of Return (IRR), Net B/C Ratio.

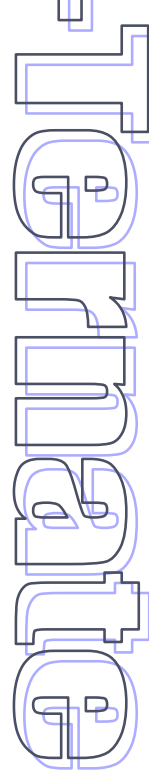

\subsection{Break Event Point (BEP)}

Break Event Point merupakan kondisi di mana total biaya produksi sama dengan nilai penjualan kacang vernis. Nilai BEp setelah dianalisis adalah $2.612,544$ bungkus, sehingga berdasarkan nilai tersebut usaha akan impas setelah penjualan mencapai $2.612,544$ bungkus.

\subsection{Payback Period (PBP)}

Payback Period adalah jangka waktu pengembalian investasi industri atau pinjaman modal. Nilai PBP juga berhubungan dengan keuntungan perusahaan sehingga semakin kecil nilai PBP maka semakin tinggi keuntungan yang diperoleh dengan nilai investasi yang sama. Hasil analisis PBP adalah 1.1 tahun, dengan demikian, modal usaha akan kembali dalam jangka waktu 1,1 tahun atau 13,2 bulan.

\subsection{Net Present Value (NPV)}

Dengan melihat nilai NPV kita dapat melihat nilai bersih usaha pada akhir umur ekonomisnya dengan menggunakan nilai suku bunga yang berlaku saat ini. Nilai NPV diperoleh dari perhitungan total present value cash flow dikurangi total investasi. Berdasarkan hasil perhitungan diperoleh nilai NPV yang positif, yaitu $R p$ 167.396.449. Hal ini menunjukkan bahwa usaha pengolahan kacang vernis layak dijalankan.

\subsection{Internal Rate of Return (IRR)}

IRR menunjukkan kemampuan suatu usaha untuk menghasilkan returns, atau tingkat keuntungan yang dapat dicapainya. Berdasarkan hasil perhitungan diperoleh nilai IRR $178 \%$, lebih besar dari bunga bank yang berlaku yaitu $9 \%$. Hal ini menunjukkan bahwa usaha pengolahan kacang vernis layak dijalankan.

\subsection{Net B/C Ratio}

Net B/C Ratio adalah merupakan perbandingan antara benefit bersih dari tahuntahun yang bersangkutan yang telah dipresent valuekan (pembilang/bersifat + ) dengan biaya bersih dalam tahun dimana Bt - Ct (penyebut/bersifat - ) yang telah dipresent valuekan, yaitu biaya kotor < benefit kotor. Berdasarkan hasil perhitungan diperoleh nilai Net B/C Ratio yaitu sebesar 6,98. Hal ini menunjukkan bahwa usaha pengolahan kacang vernis layak dijalankan.

\subsection{Analisis Biaya, Pendapatan, dan Keuntungan}

3.6.1. Biaya

Biaya yang dikeluarkan oleh usaha pengolahan kacang vernis terdiri dari biaya investasi dan biaya produksi. Perhitungan kedua biaya tersebut diperlukan dalam menentukan harga pokok penjualan dan analisis kelayakan usaha pengolahan kacang vernis. Adapun perhitungan harga diasumsikan harga yang berlaku pada bulan Mei 2016 di daerah Ternate. Harga kacang tanah sebesar Rp $22.000 / \mathrm{kg}$. 


\subsubsection{Biaya investasi}

Biaya investasi dibutuhkan dalam memulai usaha baru. Pada umumnya, biaya ini digunakan untuk keperluan pengadaan peralatan proses produksi, sarana penunjang, seperti sarana telekomunikasi dan sarana air bersih, serta surat izin usaha. Peralatan, sarana penunjang dan izin usaha memiliki umur efektif tertentu. Umur efektif dari peralatan tersebut sangat penting dalam penyusunan anggaran untuk mengganti atau membeli alat baru di masa yang akan datang serta perpanjangan izin usaha. Selain pengadaan alat, modal kerja awal juga termasuk dalam biaya investasi. Modal awal ini pada umumnya diperlukan hanya dalam jangka waktu tertentu, seperti tiga bulan atau satu tahun.

Investasi yang diperlukan untuk mendirikan industri kacang vernis sebesar $R p$ 28.004.200. Sebagian besar biaya investasi dibutuhkan untuk biaya investasi tetap yaitu sebesar 55\% atau sebesar Rp 15.505.000. Sementara untuk modal kerja awal hanya sebesar $45 \%$ atau sebesar $\operatorname{Rp}$ 12.499.200.

\subsubsection{Biaya produksi}

Biaya produksi merupakan keseluruhan biaya yang timbul dalam memproduksi kacang vernis. Biaya produksi terdiri dari biaya tetap dan biaya variabel. Biaya tetap memiliki nilai yang konstan, sedangkan biaya variabel dipengaruhi oleh kapasitas industri. Biaya tetap terdiri dari biaya administrasi dan pemasaran yang relatif konstan. Sementara biaya tidak tetap terdiri dari biaya pembelian bahan baku dan bahan pembantu proses pembuatan kacang vernis serta biaya lain yang timbul dalam proses pengolahan kacang vernis, seperti listrik, minyak tanah, kemasan, tenaga kerja, dan lain-lain.

Nilai biaya tetap pada industri kacang vernis relatif lebih kecil dari biaya tidak tetap karena bahan baku kacang vernis memiliki nilai tinggi, yaitu kacang tanah. Biaya tidak tetap mencapai $\operatorname{Rp} 382.200$ per hari atau $\operatorname{Rp} 4.586 .400$ per bulan, sedangkan biaya tetap hanya mencapai Rp 203.264 per bulan atau $R p$ 2.439.167 per tahun sebagai biaya penyusutan alat.

\subsection{Harga pokok penjualan}

Harga pokok penjualan adalah harga terendah yang ditetapkan untuk menghindari kerugian pada saat pemasaran. Sementara harga penjualan adalah harga yang ditetapkan produsen untuk memperoleh keuntungan. Produk yang sama biasanya digunakan sebagai asumsi dalam menentukan harga penjualan. Harga pokok penjualan setelah dianalisis adalah Rp 11.739,37 per bungkus. Kacang vernis dikemas dengan berat $500 \mathrm{~g}$ per kemasan. Harga jual yang ditetapkan adalah Rp 22.000 per kemasan.

\subsection{Pendapatan dan keuntungan}

Pendapatan merupakan penerimaan yang diperoleh produsen dari hasil penjualan produk. Keuntungan merupakan selisih antara harga penjualan dan harga pokok penjualan. Jika kacang vernis yang diproduksi setiap hari sebanyak 34 kemasan dengan harga jual Rp 22.000 per kemasan maka pendapatan yang diterima produsen adalah sebesar Rp 748.000 per hari atau $\mathrm{Rp}$ 107.712.000 per tahun.

Total pengeluaran per tahun sebesar $R \mathbf{p}$ 57.475.967. Dengan demikian, laba produsen per tahun dapat dihitung dengan cara mengurangi pendapatan per tahun dengan total biaya. Laba atau keuntungan yang diperoleh produsen adalah sebesar Rp 50.236.033 per tahun.

\subsection{Analisis SWOT}

\subsubsection{Penentuan Faktor Lingkungan Eksternal}

Analisis lingkungan eksternal dalam SWOT meliputi peluang dan ancaman. Berikut ini adalah berbagai faktor yang menjadi peluang dan ancaman bagi UKM kacang vernis "M. Nasir":

I. Peluang

1) Meningkatnya daya beli masyarakat.

2) Brand image produk ini sangat baik.

3) Kebijakan pemerintah untuk memberdayakan industri kecil dan rumah tangga.

4) Permintaan relatif tinggi khususnya pada perayaan hari besar keagamaan.

5) KUR bagi industri kecil dengan suku bunga rendah $(9 \%)$. 
II. Ancaman

1) Biaya produksi yang cenderung meningkat.

2) Bertambahnya merek lain di pasar.

3) Konsumen semakin sensitif terhadap harga.

4) Kenaikan tarif BBM, listrik, telepon.

5) Inflasi.

Berikut ini adalah penilaian terhadap masing-masing faktor peluang dan ancaman bagi UKM kacang vernis "M. Nasir".

Berdasarkan Tabel 1 tentang penilaian faktor eksternal dapat diketahui bahwa jumlah skor dari variabel peluang adalah 2,9 sedangkan jumlah skor dari variabel ancaman adalah 0,26 sehingga selisih yang dihasilkan antara variabel peluang dengan variabel ancaman adalah sebesar 2,64. Hal ini dapat diartikan bahwa UKM kacang vernis “M. Nasir", dalam menghadapi kondisi eksternalnya lebih banyak mempunyai peluang daripada mendapatkan ancaman. Posisi UKM kacang vernis "M. Nasir" berdasarkan selisih tersebut berada pada ordinat 2,64. Kondisi ini cukup baik bagi UKM kacang vernis “M. Nasir" untuk menghadapi lingkungan eksternalnya.

Tabel 1. Penilaian Faktor Eksternal UKM Kacang Vernis "M. Nasir"

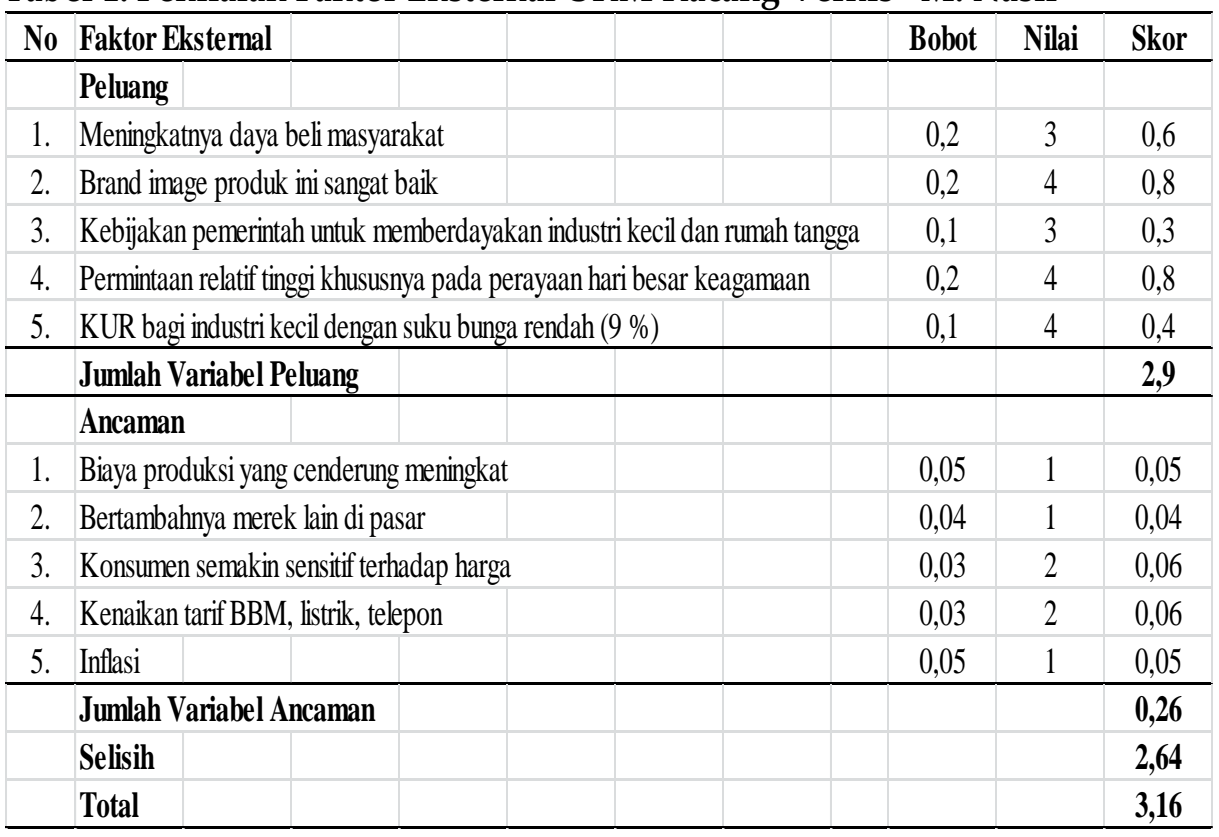

3.9.2. Penentuan Faktor Lingkungan Internal

Analisis lingkungan internal dalam SWOT meliputi kekuatan dan kelemahan. Berikut ini adalah faktor-faktor yang menjadi kekuatan dan kelemahan yang ada dalam UKM kacang vernis "M. Nasir":

I. Kekuatan

1) Kualitas produk terjamin.

2) Harga produk yang bersaing.

3) Jaringan distribusi sangat baik.

4) Tenaga kerja terampil dan pengalaman.

5) Pemasaran lokasi strategis.
6) Motivasi untuk mengembangkan usaha.

7) Kondisi keuangan.

II. Kelemahan

1) Kurangnya pelatihan dan kegiatan pendampingan dari pemerintah daerah.

2) Kurangnya modal dan pengetahuan tentang manajemen usaha.

3) Biaya produksi sangat tinggi.

Berikut ini adalah penilaian terhadap masing-masing faktor tersebut untuk mengetahui seberapa besar pengaruhnya terhadap UKM kacang vernis “M. Nasir". 
Tabel 2. Penilaian Faktor Internal UKM Kacang Vernis "M. Nasir"

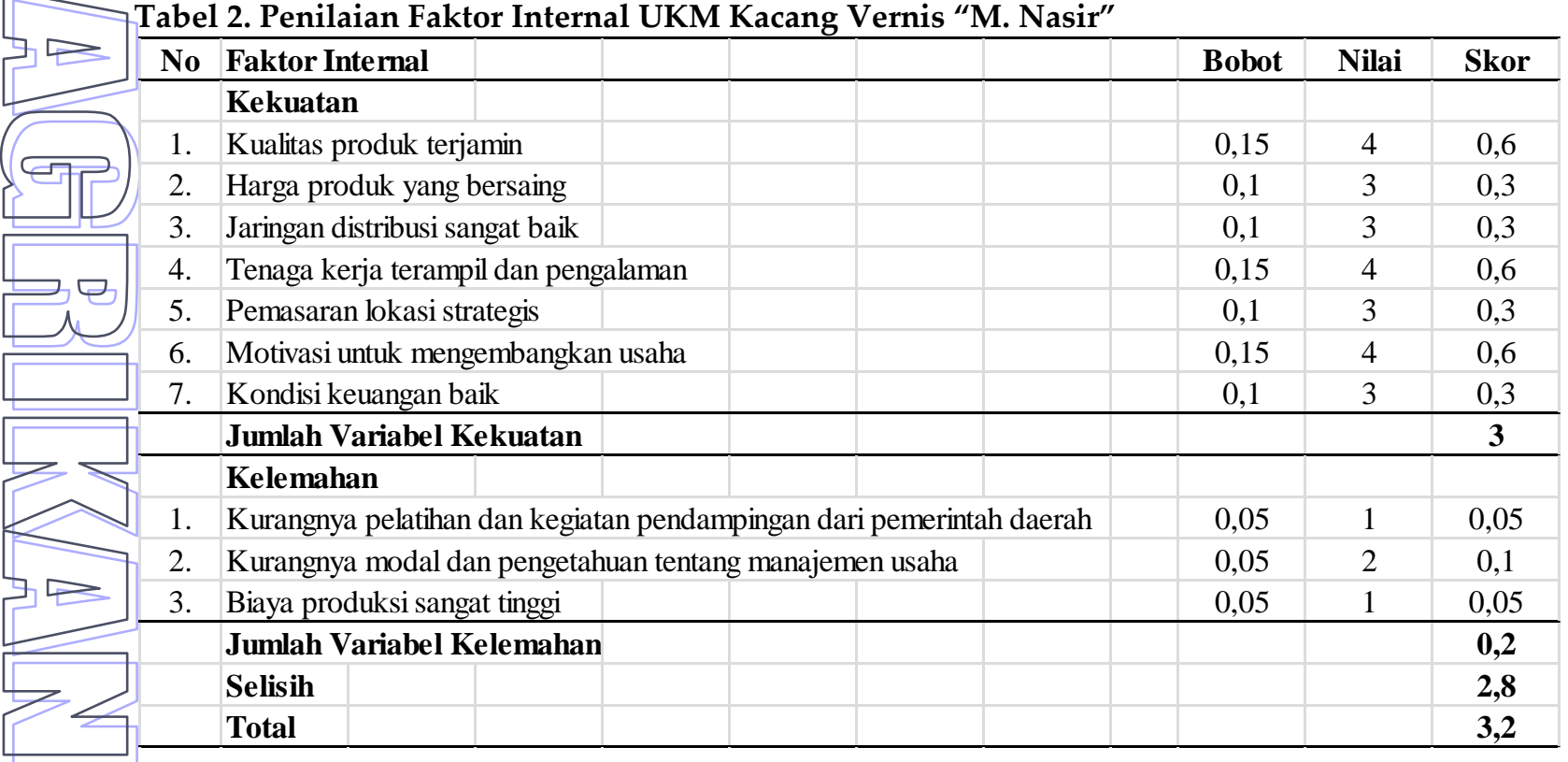

Penilaian faktor internal pada Tabel 2 dapat diketahui bahwa jumlah skor dari variabel kekuatan adalah 3, sedangkan jumlah skor dari variabel kelemahan adalah 0,2 . Hal ini menunjukkan bahwa dalam lingkungan internal UKM kacang vernis "M. Nasir", kekuatan UKM kacang vernis lebih dominan dibandingkan kelemahannya, sehingga UKM kacang vernis diharapkan mampu mengatasi kelemahan yang ada dengan memanfaatkan sebaik mungkin kekuatan yang dimiliki. Berdasarkan jumlah skor variabel kekuatan dan kelemahan tersebut maka diperoleh selisih sebesar 2,8. Dari selisih tersebut dapat diketahui bahwa posisi UKM kacang vernis "M. Nasir" berada pada absis 2,8 .

\subsubsection{Perumusan Strategi Finansial UKM} Kacang Vernis "M. Nasir"

Setelah selisih skor pada faktor eksternal dan internal diketahui, maka langkah selanjutnya adalah menggabungkan kedua selisih tersebut kedalam Matrik Grand Strategy (Diagram analisis SWOT).
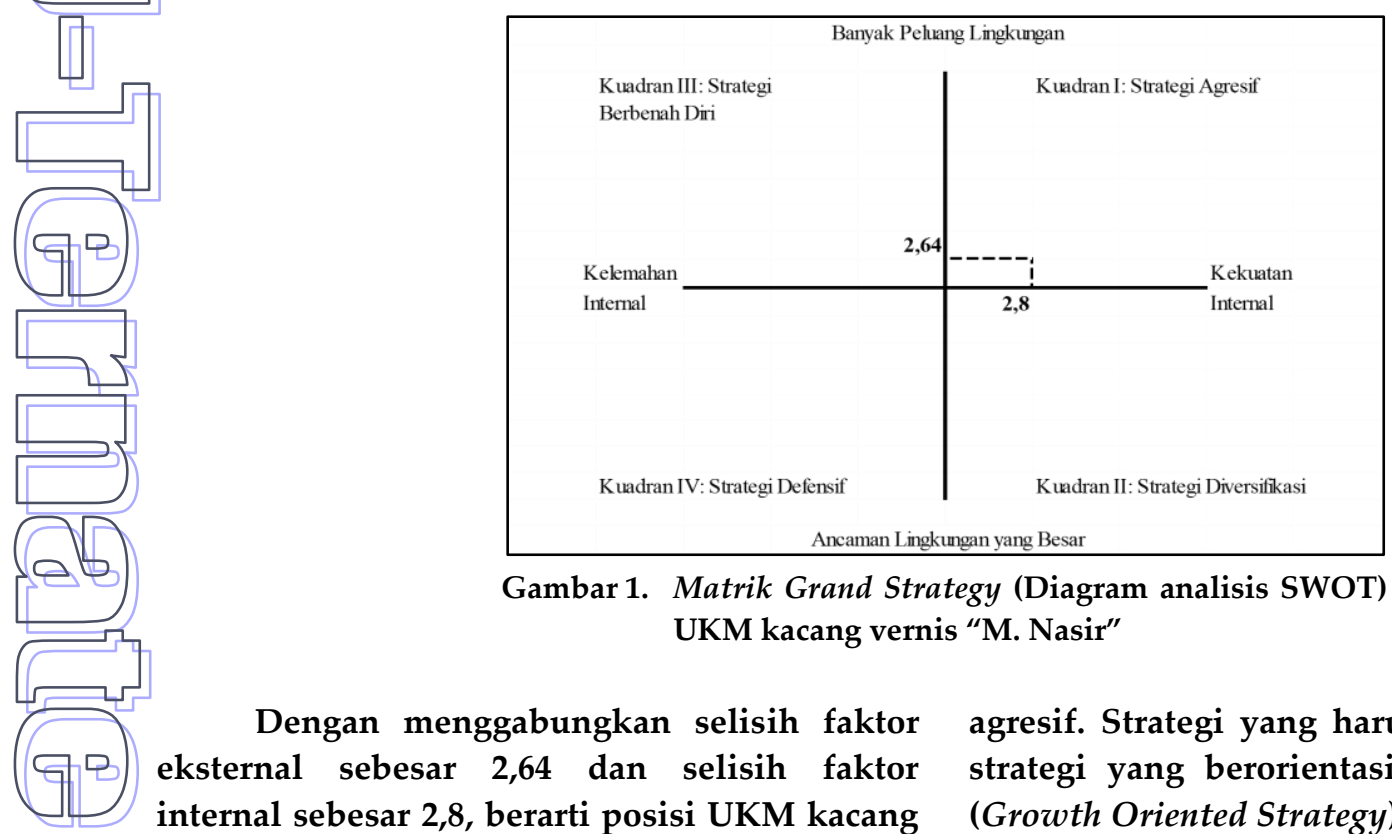

Gambar 1. Matrik Grand Strategy (Diagram analisis SWOT) UKM kacang vernis “M. Nasir"

Dengan menggabungkan selisih faktor eksternal sebesar 2,64 dan selisih faktor internal sebesar 2,8, berarti posisi UKM kacang vernis "M. Nasir" berada pada kuadran I yang berarti mendukung strategi pertumbuhan agresif. Strategi yang harus diterapkan adalah strategi yang berorientasi pada pertumbuhan (Growth Oriented Strategy).

Strategi pertumbuhan (Growth Strategy) didesain untuk mencapai pertumbuhan, baik 
dalam penjualan, aset, profit atau kombinasi dari ketiganya. Hal ini dapat dicapai dengan cara bersaing harga, mengembangkan produk baru, menambah kualitas produk atau meningkatkan akses ke pasar yang lebih luas. Usaha yang dapat dilakukan adalah dengan meminimalkan biaya (minimize cost) sehingga dapat meningkatkan profit.

Selain menggunakan Matrik Grand Strategy (Diagram analisis SWOT) maka Matrik internal-eksternal juga bisa digunakan sebagai alat untuk membantu menyusun strategi yang tepat bagi perusahaan yang didasarkan pada hasil penilaian terhadap faktor eksternal dan internal. Berdasarkan perhitungan yang telah dilakukan menunjukkan bahwa besarnya skor total dari faktor eksternal adalah sebesar 3,16, sedangkan untuk skor total dari faktor internal adalah sebesar 3,2. Dari penilaian tersebut dapat diketahui bahwa posisi perusahaan berada pada sel IV. Berikut ini adalah matrik internal eksternal dari UKM kacang vernis "M. Nasir".

Berdasarkan gambar matrik internal eksternal terlihat bahwa strategi yang tepat bagi perusahaan adalah strategi stabilitas. Penekanan strategi ini lebih banyak difokuskan pada perbaikan terhadap pelaksanaan strategi yang ada. Dengan menerapkan strategi stabilitas ini, UKM kacang vernis "M. Nasir" tidak perlu lagi mengubah arah strategi yang telah diterapkan sebelumnya.

\begin{tabular}{|c|c|c|c|c|c|}
\hline & & Tot & I Skor Faktor In & rnal & \\
\hline & & Tinggi & Sedang & Rendah & 1 \\
\hline & 4 & & & & \\
\hline & & Pertumbuhan & Pertumbuhan & Penciutan & \\
\hline & Tinggi & melalui integrasi & melalui integrasi & melalui turn & \\
\hline & & vertikal & horisontal & around & \\
\hline & 3 & SEL I & SEL II & SEL III & \\
\hline Total Skor Faktor & & Stabilitas & $\begin{array}{l}\text { Pertumbuhan } \\
\text { melahui integrasi }\end{array}$ & $\begin{array}{c}\text { Penciutan } \\
\text { melalui }\end{array}$ & \\
\hline Ekstemal & Sedang & SEL IV & horisontal & divestment & \\
\hline & & & $\overline{\text { Stabilitas }}$ & SEL VI & \\
\hline & 2 & & SEL V & & \\
\hline & & Pertumbuhan & Pertumbuhan & Bangkrut atau & \\
\hline & & melahui & melahui & likuidasi & \\
\hline & Rendah & diversifikasi & diversifikasi & SEL IX & \\
\hline & & konsentrik & konglomerat & & \\
\hline & 1 & SEL VII & SEL VIII & & \\
\hline
\end{tabular}

Gambar 2. Matrik Internal Eksternal UKM kacang vernis “M. Nasir”

Adapun penerapan strategi stabilitas pada UKM kacang vernis "M. Nasir" adalah sebagai berikut:

a. Variabel produk

1. Menjaga kualitas produk

2. Menambah kuantitas produk khususnya kacang vernis yang ukuran kemasannya kecil

3. Menjaga kemasan produk

b. Variabel harga

1. Mempertahankan harga yang sudah ditetapkan selama ini.

2. Jika kenaikan harga produk tidak bisa dihindarkan, maka produsen bisa menaikkannya secara bertahap agar dapat menutup biaya produksi dan transportasi sampai batas tertentu yang tidak mencolok bagi konsumen.

c. Variabel distribusi
1. Memasarkan produk di tempat-tempat yang mudah dijangkau oleh konsumen

2. Memperluas jangkauan pemasaran

d. Variabel promosi

1. Meningkatkan kegiatan promosi

2. Memberikan hadiah bagi konsumen yang membeli kacang vernis dalam jumlah tertentu.

\section{PENUTUP}

1. Hasil analisis kelayakan finansial UKM kacang vernis "M. Nasir" menunjukkan bahwa usaha ini layak dan menguntuntungkan karena memberikan nilai NPV yang positif, yaitu sebesar Rp 167.396.449, nilai IRR sebesar $178 \%$, atau lebih besar dari bunga bank yang berlaku yaitu 9\%, nilai Net B/C Ratio yaitu sebesar 
6,98, nilai BEP sebesar 2.612,544 bungkus dan nilai PBP sebesar 1,1 tahun.

2. Hasil analisis biaya, pendapatan, dan keuntungan diketahui bahwa usaha kacang vernis mengeluarkan biaya sebesar $R p$ 57.475.967 per tahun yang terdiri dari biaya tetap sebesar $R p$ 2.439.167 dan biaya variabel sebesar Rp 55.036.800. Pendapatan yang diperoleh produsen dari usaha kacang vernis adalah sebesar $R p$ 107.712.000 per tahun. Laba atau keuntungan yang diperoleh produsen adalah sebesar $\mathrm{Rp}$ 50.236.033 per tahun.

3. Strategi yang tepat bagi UKM kacang vernis "M Nasir" adalah strategi stabilitas. Penekanan strategi ini lebih banyak difokuskan pada perbaikan terhadap pelaksanaan strategi yang sudah ada.

\section{DAFTAR PUSTAKA}

BPS, 1999. Statistical Year book of Indonesia 1998. Biro Pusat Statistik. Jakarta.

Erlina, 2006. Analisis Perancangan Agroindustri BerbasisKaret. Jurnal Bisnisdan Manajemen, 3(1):73-92.

Firmansyah, B.A., A. Veronika, B. Trigunarsyah.2006.Risk Analysis In Feasibility Study Of Building Construction Project: Case Study-PT. Perusahaan Gas Negara Indonesia. The Tenth East Asia-Pacific Conference on Structural Engineering and Construction, Bangkok, Thailand Tahun 2006. Bangkok 3-5Agustus, Thailand.

Kusuma, P.T.W.Wet al. 2010. Financial Analysis Pengembangan Usaha Kecil Menengah (UKM) Produsen Flakes Ubi Jalar (EmergencyFood) (Studi Kasus UKM Mandiri Pangan Mapan Makmur, Gunung Kidul). Proceeding Seminar on Applicationand Researchin Industrial Technology 2010 (SMART) Tahun 2010 :C1- C6. Yogyakarta, 29 Juli 2010 : Universitas Gadjah Mada Yogyakarta.

Mc. Keough,P., et. al. 2005. Techno-economic Analysis of Biotrade Chains. Proceeding Upgraded Biofuelsfrom Russia and Canadato the Netherlands Espoo2005. ResearchVTT Tiedotteita. Research Notes 2312.pp.25.

National Association of Certified Valuation Analysts. 2005. Analysis of The Statement of Cash Flow and Financial RatioAnalysis, Fundamentals, Techniques \&Theory 1995-2005.

Rantala,J., P. Harstela,V.M SaarinenandL. Tervo. 2010. A Techno-Economic Evaluation Of Bracke And M-Planter Tree PlantingDevices. Research Article The Finnish Society of Forest Science ISSN0037-5330. The Finnish Forest Research Institute Silva Fennica:p43(4).

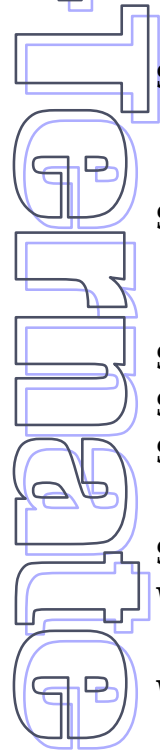

Sandee, H., Rietveld, P., Supratikno, H., dan P. Yuwono. 1994. "Promoting Small Scale and Cottage Industries in Indonesia: An Impact Analysis for Central Java". Bulletin of Indonesian Economic Studies.30 (3).115-42.

Simatupang Pantjar, Togatorop M.H, Sitompul, Rudy P, Tulus Tambunan. (eds.). 1994. Prosiding Seminar Nasional Peranan Strategis Industri Kecil Dalam Pembangunan Jangka Panjang Tahap II. UKI-Press. Jakarta.

Soekartawi, 1991. Dasar Penyusunan Evaluasi Proyek. Pustaka Sinar Harapan. Jakarta.

Soekartawi, 2006. Analisis Usahatani. UI-Press. Jakarta.

Sudisman U,A. Sari, 1996. Undang-Undang Usaha Kecil 1995 dan Peraturan Perkoperasian. Mitrainfo. Jakarta.

Sutojo S, 2000. Studi Kelayakan Proyek,Teori dan Praktek. Jakarta: Gramedia.

Weijland H, 1999. "Microenterprise Clusters in Rural Indonesia: Industrial Seedbed and Policy Target". World Development.27 (9).1515-30.

Wolf OM,etal.2005. Techno-economic Feasibility of Large Scale Production of Bio- based Polymers in Europe. Technical Report Series EuropeanCommission. Institute for Prospective Technological studies, Jointresearch, ISBN 92-79-01230-4, Technical Report EUR22103EN. 